\title{
Ecosystem services and disservices associated with pastoral systems from Patagonia, Argentina - A review
}

\author{
Pablo Tittonell ${ }^{1,2,3,4,{ }^{*} \text { (D) Sofía M. Hara }}{ }^{1}$ (D), Valeria E. Álvarez ${ }^{1}$ (D) Valeria M. Aramayo ${ }^{1}$ (D) \\ Octavio A. Bruzzone ${ }^{1}$ (D), Marcos H. Easdale ${ }^{1}$ (D), Andrea S. Enriquez ${ }^{1}$ (D), Luciana Laborda ${ }^{1}$ (D), \\ Fabio D. Trinco ${ }^{1}$, Sebastián E. Villagra ${ }^{1,5}$ and Verónica El Mujtar $^{1}$ (D)
}

1 Agroecology, Environment and Systems Group, Instituto de Investigaciones Forestales y Agropecuarias Bariloche (IFAB), INTACONICET, Modesta Victoria 4450, CC 277, San Carlos de Bariloche 8400, Río Negro, Argentina

${ }^{2}$ CIRAD (Centre de Coopération Internationale en Recherche Agronomique pour le Développement), UPR AIDA, F-34398 Montpellier, France

3 AIDA, Univ Montpellier, CIRAD, Montpellier, France

${ }^{4}$ Groningen Institute of Evolutionary Life Sciences, Groningen University, PO Box 11103, 9700 CC Groningen, The Netherlands

${ }^{5}$ Universidad Nacional de Río Negro, Cátedras de Rumiantes Menores y Sistemas de Producción de Bovinos en Regiones Frágiles, Licenciatura en Agroecología, 8400 El Bolsón, Argentina

\begin{abstract}
Pastoral systems worldwide secure rural livelihoods in the harshest environments on Earth. Their low productivity per area unit or head makes them the subject of much criticism with regard to their environmental impact, particularly in relation to global warming, desertification and land degradation. Such is the case of the traditional pastoral systems of Patagonia, a vast and isolated region where sedentary and mobile pastoralism coexist and contribute to shape landscapes and cultures. We argue that pastoral systems provide a wide range of ecosystem services that may compensate for their negative impact on the environment. We review the scarcely available evidence from Patagonia to identify ecosystem services and disservices associated with pastoralism, and pay special attention to the carbon balance: with $\mathrm{C}$ footprints between 10 to $40 \mathrm{~kg} \mathrm{CO}_{2}$-eq. $\mathrm{kg}^{-1}$ carcass, pastoral systems in dry Patagonia are below or within the range of semi-extensive livestock systems worldwide (35-45 $\mathrm{CO}_{2}$-eq. $\mathrm{kg}^{-1}$ carcass). To inform development and policy, the assessment of trade-offs and synergies between ecosystem services needs to incorporate the intertwined social and ecological dynamics of complex pastoral systems, along resource regenerative trajectories.
\end{abstract}

Keywords: environment / sustainability / pastoralism / livestock / drylands / highlands / ecosystem services

Résumé - Services écosystémiques et dis-services associés aux systèmes pastoraux de Patagonie, Argentine-Revue bibliographique. Les systèmes pastoraux du monde entier garantissent des moyens de subsistance aux ruraux dans les environnements les plus difficiles de la planète. Leur faible productivité par unité de surface ou par habitant suscite de nombreuses critiques quant à leur impact environnemental, notamment en relation avec le réchauffement climatique, la désertification et la dégradation des terres. C'est le cas des systèmes pastoraux traditionnels de Patagonie, une région vaste et isolée où le pastoralisme sédentaire et nomade coexistent et contribuent à façonner les paysages et les cultures. Nous soutenons que les systèmes pastoraux fournissent un large éventail de services écosystémiques qui peuvent compenser leur impact négatif sur l'environnement. Nous passons en revue les données disponibles sur la Patagonie pour identifier les services écosystémiques et les dis-services associés au pastoralisme, en accordant une attention particulière au bilan carbone: avec des empreintes carbone entre 10 et $40 \mathrm{~kg} \mathrm{CO}_{2}$-éq $/ \mathrm{kg}$ de viande, les systèmes pastoraux en Patagonie aride sont en dessous ou dans la gamme des systèmes d'élevage semi-extensifs dans le monde (35-45 éq- $\mathrm{CO}_{2} / \mathrm{kg}$ de viande). Pour éclairer les options de développement et

*Corresponding author: tittonell.pablo@inta.gob.ar 
les politiques, l'évaluation des compromis et des synergies entre services écosystémiques doit intégrer l'entrelacement de dynamiques sociales et écologiques, dans des systèmes pastoraux complexes, au fil de trajectoires de régénération des ressources.

\begin{abstract}
Mots clés : environnement / durabilité / pastoralisme / élevage / terres arides / hauts plateaux / services écosystémiques
\end{abstract}

\section{Introduction}

Pastoral systems worldwide provide livelihoods for rural families in a wide diversity of social-ecological contexts, but particularly in the harsh environments of arid rangelands and high mountain pastures. About 1 billion animals are herded by pastoralists, covering the basic needs for food, fibre, monetary incomes, workforce, energy, transportation and savings of millions of people (FAO, 2018). Pastoral herds play a central role at ensuring food and nutritional security of rural as well as urban families worldwide (e.g., Randolph et al., 2007), they are the backbone of the rural cultural inheritance in different regions (e.g., Marsoner et al., 2018) and represent a valuable investment/saving asset for rural peoples (e.g., Paul et al., 2020). This is also the case in Patagonia, where pastoral systems include both sedentary and mobile ranching systems relying on natural vegetation (Fig. 1A).

Worldwide, extensive livestock rearing is seen as responsible for negative environmental impacts such as vegetation and soil degradation, water pollution and greenhouse gas emissions (Modernel et al., 2018). This bias also resulted in pastoral system being seen as a threat to environmental sustainability, especially when analysed with the methods and assumptions used to assess intensive or industrial livestock systems (e.g., Lebacq et al., 2013). There is evidence to suggest that pastoral systems generate both ecosystem services and disservices, hence the trade-offs between them need to be embraced to inform development strategies and policies (e.g., Von Thungen et al., 2021).

In virtue of the strong bonds between the social and ecological dynamics, pastoral systems can be conceptualized as complex systems, i.e., they integrate processes across scales, multiple feedbacks, nested hierarchies and non-linearity (Tittonell, 2014). The ecological sub-system results in and is the result of the social sub-system, of its traditional ecological knowledge (e.g., seasonal usage of lowlands and highlands), cultural values, social and productive organization (e.g., mobility and landscape connectivity), and technologies (e.g., local breeding). Pastoral communities in harsh environments such as the Patagonian steppes and mountains have developed adaptive strategies to cope with spatial and temporal variability in climate and natural resources. An important strategy is mobility: i.e., nomadism, transhumance, semisedentarism. This lifestyle and its associated ecosystem services, which depend on traditional ecological knowledge and local institutions (Easdale and Aguiar, 2018; Oteros-Rozas et al., 2013), is currently threatened by social, economic and environmental factors.

We hypothesize that the contribution of traditional pastoral systems to livelihoods and ecosystem services (Fig. 2), hence to some of the key sustainable development goals, may compensate for their negative effects on the environment. We focus our analysis on the relatively poorly studied pastoral systems of Patagonia, a vast region covering $1043000 \mathrm{~km}^{2}$ and where transhumant, semi-sedentary and sedentary ruminant livestock-based activities represent the dominant livelihood for rural families, from the humid Andes to the dry steppes and irrigated valleys. Our objective was to take stock of the scarcely available evidence on ecosystem services and disservices associated with the regional diversity of pastoral systems, using first-hand evidence whenever possible, and make it available for further evidence-based trade-offs analysis, informing regional and international debates on livestock sustainability.

\section{Diversity of pastoral systems in Patagonia}

Extensive livestock farming is the main economic activity in Patagonia ( 750000 ha; 8.5 million heads - ovine equivalents), including both family smallholder pastoralism and large-scale ranching. Smallholder pastoralism is the dominant farming type, rearing mixed-species herds of sheep, goats and cattle. Large scale ranches are more specialized in sheep and, to a lesser extent, cattle production (Fig. 1). Between smallholder pastoralism and ranching, there is a gradient of possible different livestock systems that combine elements of both family farming and commercial ranching. Argentina's Ministry of Agriculture proposes maximum benchmark land areas as part of their definition of what a family farm is for each agroecological region of the country. In dry Patagonia, a smallholder family farm is considered to own or manage less than 5000 ha of rangeland (Coordinación de Agricultura Familiar: Resolución 186/14).

The breeding of Merino sheep oriented to the production of fine wool is the most important livestock activity for both ranchers and pastoralists throughout Patagonia, followed by the Angora and Creole goat and, to lesser extent, Hereford and Creole cattle (Villagra et al., 2013). For example, a regional study covering 106 smallholder households in north Patagonia and its diversity of systems (Fig. 1) showed that livestock contribution to household income was greater than $96 \%$, especially by sheep, and that a sharp decline of wool prices resulted in outmigration of $42 \%$ of the rural population in the 1990s (Villagra et al., 2015). Next to sheep, goat rearing is also common and it generally promotes the settlement of families in the driest areas of the region, where productivity is low and other farming activities are not possible. In wetter areas, goat rearing is a secondary activity yet less prone than other livestock activities to the risks associated with the macroeconomic situation of the country or the variability in the international wool and meat prices.

At the wettest end of the gradient, on the Patagonian forests (Fig. 1), farmers keep small to large herds of cattle (e.g., less than ten to hundreds, exceptionally up to 700 Livestock Units), 


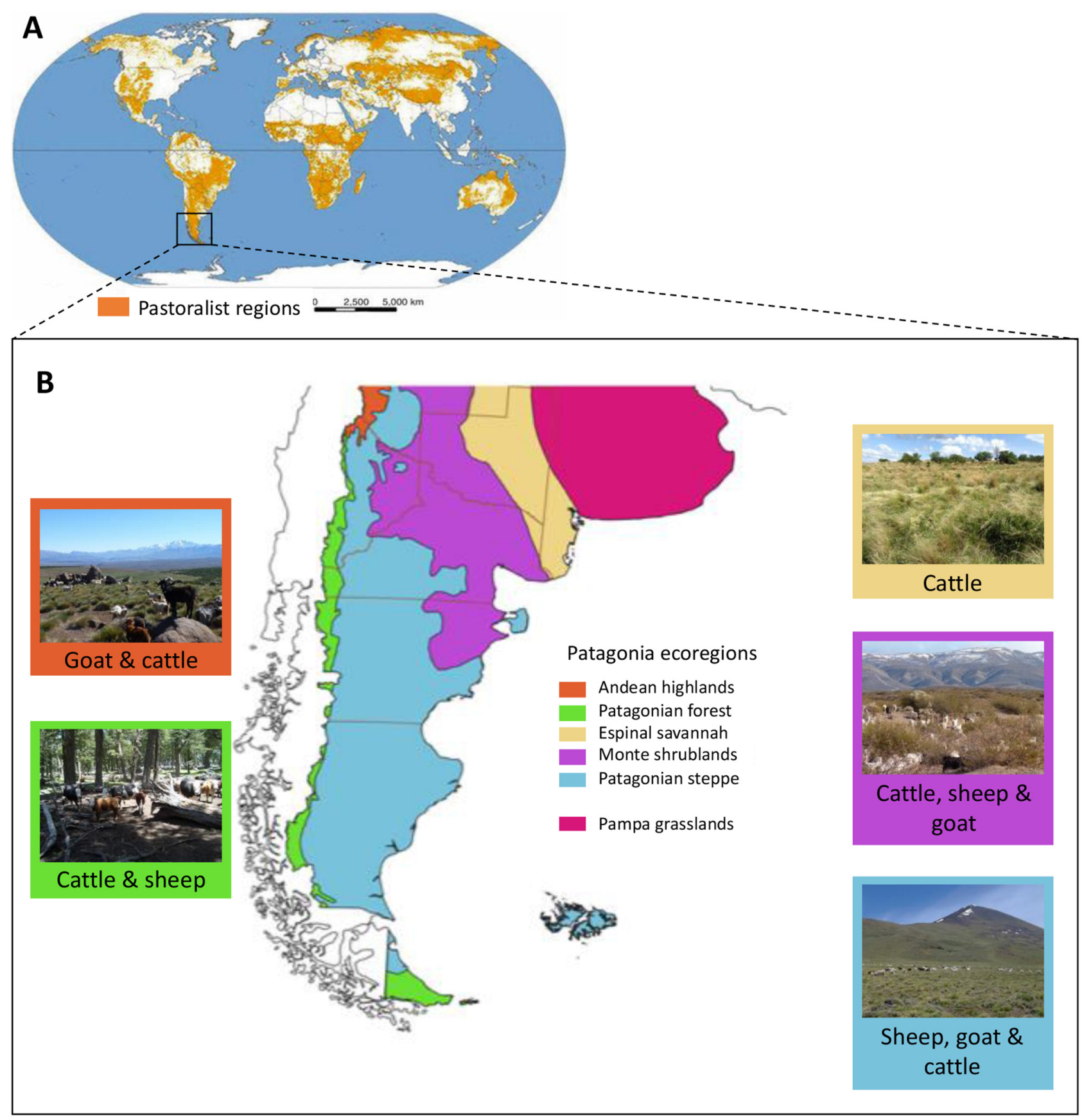

Fig. 1. (A) World pastoralist regions highlighting the Patagonia region (adapted from Dong, 2016). (B) Livestock systems in Patagonia ecoregions (adapted from ANP, 2020) with illustrative pictures. The Pampa's region, and the northern parts of the Monte and Espinal regions (not shown in picture) are not part of Patagonia.

Fig. 1. (A) Régions pastorales mondiales et mise en évidence de la région de Patagonie (adapté de Dong, 2016). (B) Systèmes d'élevage dans les écorégions de Patagonie (adapté de l'ANP, 2020) avec des images illustratives. La région de la Pampa et les parties septentrionales des régions de Monte et Espinal (non représentées en photo) ne font pas partie de la Patagonie.

following a strategy characterised by large head numbers but low productivity per head (i.e., livestock as savings). Winter grazing takes place in valley bottoms and foothills (500 to 900 m.a.s.1.), while summer grazing makes use of the high forest, shrublands and alpine-type meadows (1000 to $1800 \mathrm{~m}$. a.s.1.), areas which are covered in snow for most of the rest of the year. In the past, people used to open grazing areas through fires, although this practice has been reverted over the last century, especially since forest use became regulated by law (e.g., Gowda et al., 2012).

In North-West Patagonia, transhumant goat-based pastoralism interconnects contrasting and fragmented ecosystems 
through seasonal movements. Dry winter lowlands (Patagonian steppe and Monte shrublands - Fig. 1) connect with wet summer highlands (Andean highlands and Patagonian forests Fig. 1) through regional networks in which the social and ecological phases of these movements are synchronized, defining an annual transhumant cycle (Pérez León et al., 2020). Summer highlands are typically meeting areas where pastoralists exchange or sell breeds (i.e., creole goats) and livestock products such as cheese or meat, textile and leather handicrafts, and engage in different joint activities such as marking and shearing, organise logistics (e.g., travel to town), festivals or religious gatherings. Key components of the transhumance system are also the herding or migratory roads, which are common lands that interconnect the different communal pasturelands (Lanari et al., 2012).

\section{Key ecosystem services and disservices associated with pastoral systems}

Here we summarise the available regional evidence on the effects pastoral systems may have on ecosystem services and disservices associated with (i) watershed protection and nutrient cycling (support and regulation), (ii) plant and soil biodiversity conservation (support and regulation), (iii) the carbon balance (which may be both a service or a disservice), and (iv) cultural ecosystem services (Fig. 2). The choice of ecosystem services to investigate responds to what is available so far in the literature. The ecosystem services forage or animal production (provision) are by large the best studied in Patagonia, hence we will consider them only with regards to their trade-offs against other ecosystem services.

\subsection{Watershed protection and nutrient cycling at landscape level}

Stocking rate, directly related to grazing pressure, is the main management variable regulating grazing impacts on ecosystem services in Patagonia (Oñatibia, 2021). Stocking rates can be lower, equal or higher than field carrying capacity (varying broadly between 0.10 to 0.35 sheep ovine equivalents $\mathrm{ha}^{-1}$ ), resulting in low, moderate or overgrazing. Limiting stocking rates to field carrying capacity (i.e., moderate or appropriate grazing) can provide watershed protection by regulating soil cover and the amount, timing and quality of water and sediment flows and soil water infiltrability. Overgrazing negatively affects these structural attributes, with consequent water run-off and soil erosion (López et al., 2013).

Signs of overgrazing are conspicuous in Patagonia and attributed to both domestic and wild herbivores, mostly through classical lineal analysis of NDVI trends from satellite imagery series (e.g., Gaitán et al., 2017, 2019; Mazzonia and Vazquez, 2009; Marino et al., 2020; Oliva et al., 2020). Yet recently published data from long-term grazing experiments indicate that moderate and adaptive grazing regimes (i.e., following recommended stocking rates) may actually result in greater short- and long-term productivity and stability (Oliva et al., 2020). Moreover, the analyses of long-term NDVI trends in satellite imagery using wavelets - instead of linear trends - to capture cyclical dynamics (Easdale et al., $2018,2019)$ show that processes of vegetation recovery are also frequent throughout Patagonia, in spite of recurring droughts and ash falls affecting vast regions in the last two decades (Solano-Hernandez et al., 2020).

Grazing intensity and management determine different patterns of livestock impacts on nutrient cycling (Tab. 1). In the silvo-pastoral systems found in the Andean forest zone (Fig. 1), overgrazing generates more negative than positive effects at stand level, while low to moderate grazing leads to null or positive impacts on $\mathrm{C}$ and $\mathrm{N}$ flows and stocks in different components of soil and vegetation. Heterogeneous distribution of patches of silvo-pastoral use within the landscape allowed the maintenance of diversity and the provision of multiple ecosystem services, including nutrient cycling through faster litter decomposition and animal dejections (Chillo et al., 2018). In Patagonian irrigated valleys, where diverse types of agricultural systems coexist with pastoralism, circular farming and crop-livestock integration have been proposed to reduce dependence on external nutrient inputs at local and regional level, considering the coexistence of farms with nutrient demands and farms with a potential excess of manure (Basso, 2018).

In the Patagonian steppe, where water and nutrients are scarce, forage supply and $\mathrm{C}$ and $\mathrm{N}$ storage were highest in areas under moderate grazing, compared to ungrazed and overgrazed areas, and they were positively correlated indicating the absence of trade-offs between them (e.g., Oñatibia et al., 2015). Comparable findings were reported by Buono et al. (2011) and Oliva et al. (2012, 2020). These findings are promising as they point to possible synergies or neutral effects of moderate pastoral grazing on nutrient stocks and flows, specially under so-called "holistic management" (Cibils et al., 2014). Yet, our general impression following the literature review is that this field is still very poorly studied in Patagonia, especially in the drier zones, and hence more knowledge is needed to arrive at sound conclusions and recommendations. What can be considered an "appropriate" grazing regime or stocking rate varies widely across time and space in Patagonia, but it always implies that stocking rates should be equal to the estimated grassland receptivity.

As grazing may prevent fires, especially in woodland ecosystems, it may also contribute to maintaining soil physical properties, avoiding post-fire hydrophobicity and reducing soil erosion susceptibility (Neary and Leonard, 2020). In the Monte shrublands ( $c f$. Fig. 1) for example, where wildfires are more frequent, grazing reduces the occurrence of fires (Kröpfl et al., 2015). While herbivore impact on fire propagation depends on the context (Blackhall et al., 2017), drivers of current wildfires in Patagonia include also climate change and urbanization (Gowda et al., 2012).

\subsection{Plant and soil biodiversity conservation}

Grazing has been reported to have different direct effects, positive or negative, on species richness, cover and biomass of palatable grasses, and null impact on cover and biomass of shrubs in Patagonian drylands (Cipriotti et al., 2019; Oñatibia et al., 2018). However, excluding livestock does not appear to be the most sensible measure to manage plant biodiversity. Compared to grazing exclusion, continuous moderate grazing maintains plant density of palatable species, reduces standingdead biomass proportion, and promotes green biomass of grass 


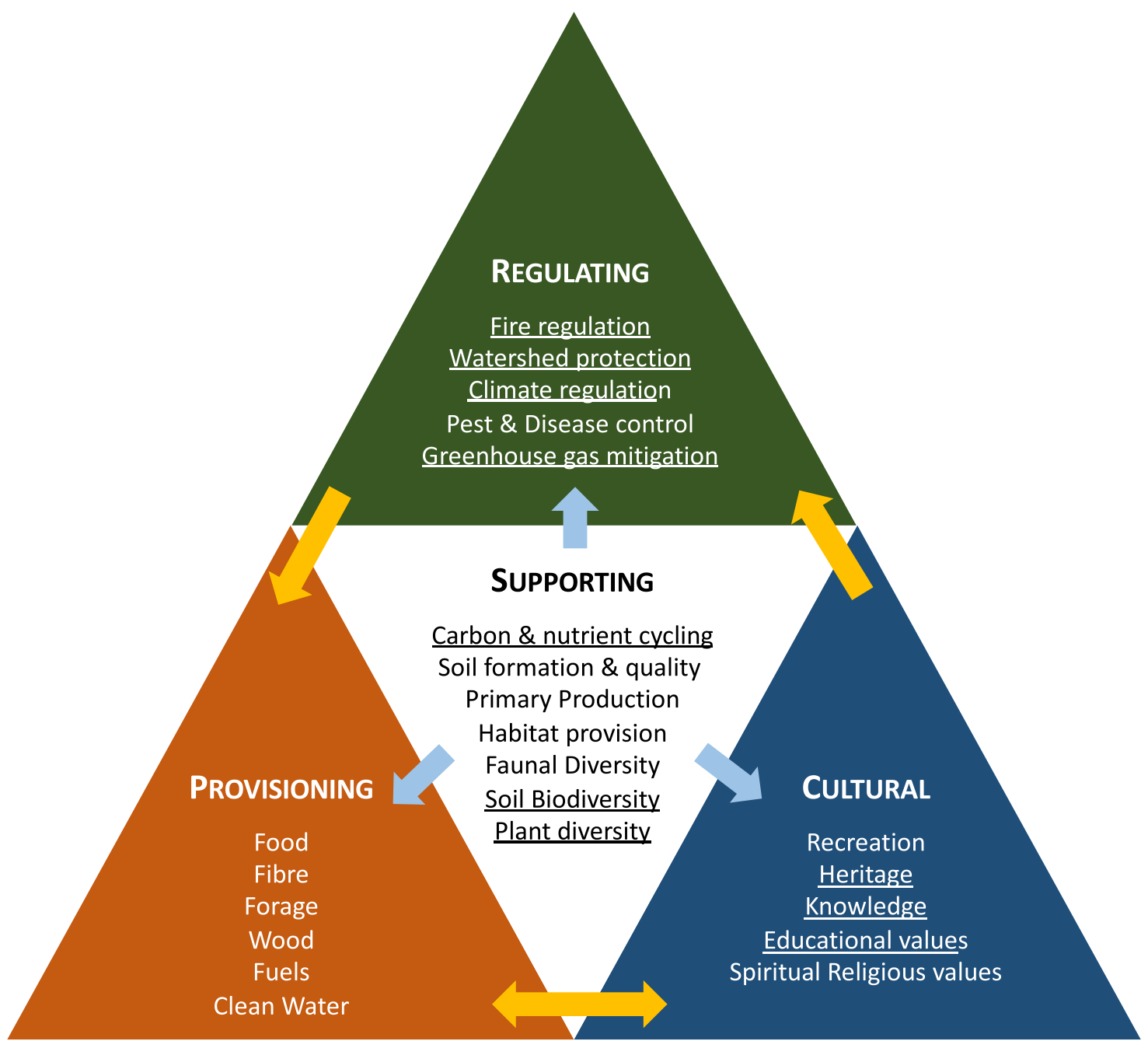

Fig. 2. Four types of ecosystem services relevant to pastoral social-ecological systems. Underlined are those that were covered in this review for Patagonia. Arrows represent both effects and influences.

Fig. 2. Quatre types de services écosystémiques pertinents pour les systèmes socio-écologiques pastoraux. Ceux qui ont été traités dans cette revue bibliographique sur la Patagonie sont soulignés. Les flèches représentent à la fois les effets et les influences.

tussocks (e.g., Oñatibia and Aguiar, 2019). Reduction of paddock sizes (NB: a "paddock" may be as large as 5001000 ha in dry Patagonia) also contributes to the decrease of spatial heterogeneity of grazing impacts, as vegetation variables (e.g., total and specific plant cover, vegetation patchiness) in smaller paddocks reach a plateau at short distance of watering points compared to larger paddocks (Oñatibia and Aguiar, 2018).

Mainly negative impacts of cattle grazing on plant biodiversity have been reported in Patagonian ecosystems (Fig. 3). Recent studies in northern Andean mixed forests of Nothofagus dombeyi and Austrocedrus chilensis suggest that cattle grazing affects plant biomass, reduces shrub cover and the number of native plants, differentially affects flowering and fruiting periods of palatable and non-palatable species, and enhances exotic plant species (e.g., Ballari et al., 2020, De Paz and Raffaele 2013). Experiences in southern Patagonian Nothofagus antarctica forests, however, showed that, through active ecosystem management, cattle production can coexist with native plant biodiversity (Peri et al., 2016). This study shows that when cattle were introduced, some species of native vascular plants were lost from grazed plots, and simultaneously new ones appeared. Although this generated similar values of biodiversity in terms of both richness and cover in these landscapes (Fig. 4), the loss of native species cannot be compensated for its biodiversity value, and specific measures (e.g., grazing exclosures) must be taken to preserve native vascular plant diversity.

Synergies between provision and cultural ecosystem services through grazing management have also been reported in the Andean forest region of Patagonia. Chillo et al. (2018) showed perceivably positive changes in the floristic and functional diversity of herbaceous vegetation associated with grazing, for example through the appearance and dominance of exotic and native grasses with high cultural and productive value.

Moreover, in grazed areas of northern Patagonian forests, changes in community specific leaf area and weighed $\mathrm{N}$ content resulted in greater plant growth and cover (less soil erosion) and faster litter decomposition (higher nutrient 
Table 1. Examples of reported negative, positive or null impacts of livestock systems on nutrient cycling.

Tableau 1. Exemples d'impacts négatifs, positifs ou nuls des systèmes d'élevage sur le cycle des nutriments.

\begin{tabular}{|c|c|c|c|c|}
\hline Variable & Negative impact & Positive impact & Null impact & References \\
\hline $\mathrm{C}$ and $\mathrm{N}$ stock in standing dead biomass & grass-OG & & shrub-UG, MD, OG & \\
\hline $\mathrm{C}$ and $\mathrm{N}$ stock in roots & & & $\mathrm{UG}, \mathrm{MD}, \mathrm{OG}$ & \\
\hline total N, NH4+ and NO3- & OG & & & Enriquez et al. (2014) \\
\hline $\begin{array}{l}\mathrm{C} \text { stock in roots }+\mathrm{SOC} \\
(=\text { total below ground } \mathrm{C} \text { storage })\end{array}$ & & & $\mathrm{LG}, \mathrm{MD}, \mathrm{OG}$ & Larreguy et al. (2014) \\
\hline SOC & $\mathrm{OG}$ & & & Larreguy et al. (2014) \\
\hline $\mathrm{SOC}$ & & & $\mathrm{UG}, \mathrm{MD}, \mathrm{OG}$ & Golluscio et al. (2009) \\
\hline SON & $\mathrm{OG}$ & & & \\
\hline${ }^{13} \mathrm{C} \mathrm{SOM}$ & $\mathrm{OG}$ & & & \\
\hline${ }^{15} \mathrm{~N}$ SOM & & $\mathrm{UG}$ & & \\
\hline $\mathrm{N}$ and $\mathrm{C}$ mineralization & $\mathrm{OG}$ & & & \\
\hline Litterfall & SVP & & & \\
\hline $\mathrm{SOC}$ & SVP-OG & & & Chillo et al. (2018) \\
\hline
\end{tabular}

LG, MG and OG: low, moderate and overgrazing; UG: ungrazed sites; SVP: sylvo-pastoral system; SOC: soil organic carbon; SON: soil organic nitrogen; SOM: soil organic matter.

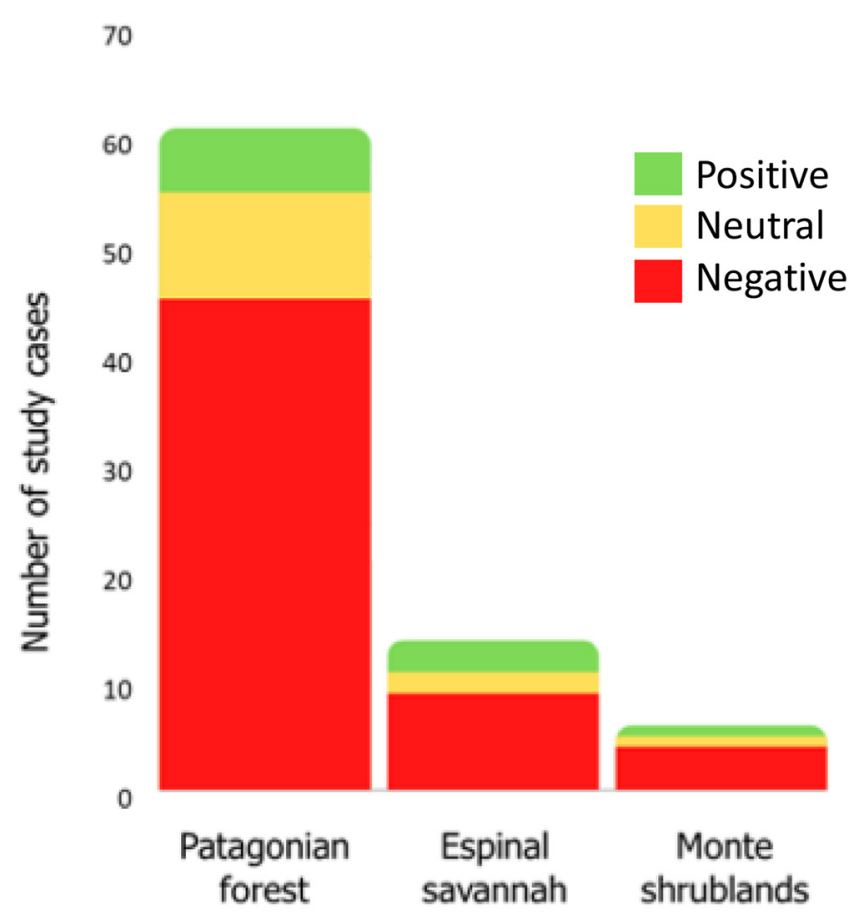

Fig. 3. Effects of cattle on plant biodiversity of Patagonian ecosystems. Adapted from Mazzini et al. (2018).

Fig. 3. Effets des bovins sur la biodiversité végétale des écosystèmes de Patagonie. Adapté de Mazzini et al. (2018).

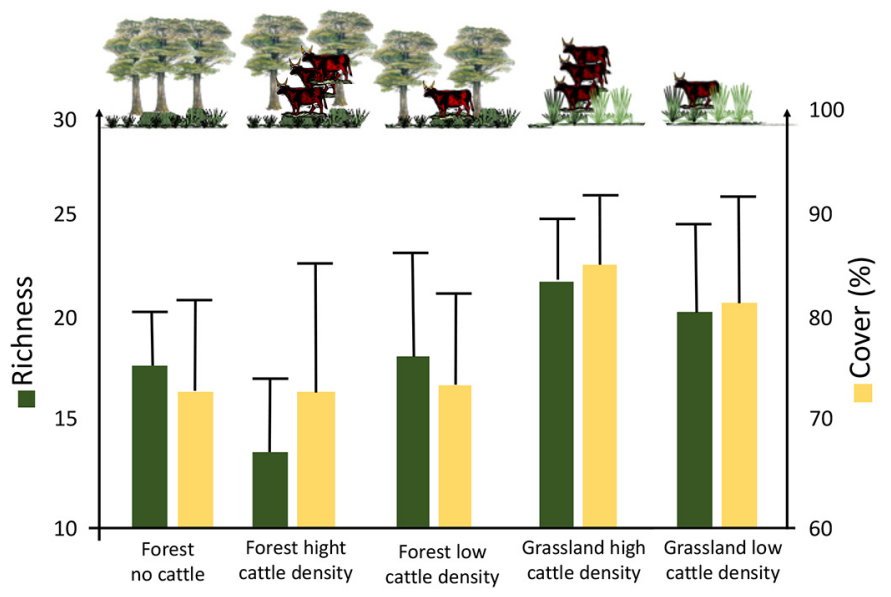

Fig. 4. Impact of different livestock grazing pressure over vascular plants (richness and cover) in Nothofagus antarctica forests and grasslands. Adpted from Peri et al. (2016).

Fig. 4. Impact de différentes pressions de pâturage exercées par le bétail sur les plantes vasculaires (richesse et couvert) dans les forêts et les prairies à Nothofagus antarctica. Adapté de Peri et al. (2016).

supply), which consequently determined greater forage productivity (Chillo et al., 2018). Yet high cattle stocking rates in forests may prevent forest regeneration, as the dominance of exotic grasses tend to outcompete tree seedlings (Rusch et al., 2016), compromising all ecosystem services associated with forest in the long term. Grazing regimes in 
Table 2. Livestock impact on biological indicators of soil biodiversity.

Tableau 2. Impact des systèmes d'élevage sur les indicateurs de biodiversité du sol.

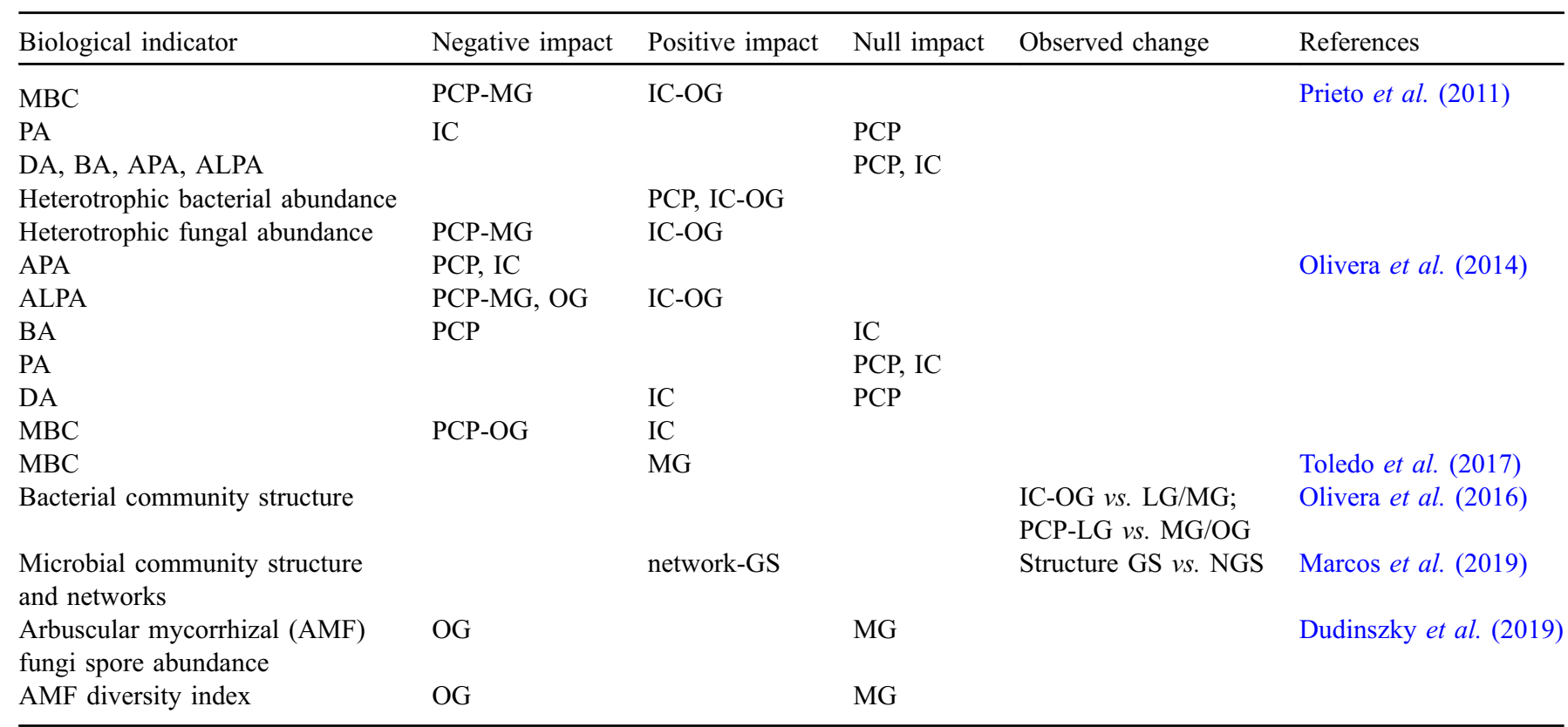

MBC: microbial biomass carbon; PA, DA, BA, APA, ALPA: protease, dehydrogenase, $\beta$-glucosidase, acid and alkaline phosphatase activity; PCP: plant-covered patches; IC: nearest inter-canopy areas; LG, MG and OG: low, moderate and overgrazing; NGS and GS: non-grazed and grazed sites.

Andean forests must be carefully designed to maintain forest coverage in the long term (Raffaele et al., 2011).

In the soil, biodiversity supports and regulates multiple processes and is therefore crucial for ecosystem functioning and services (El Mujtar et al., 2019). Grazing affects soil physico-chemical properties, and hence biodiversity, but impacts differ according to grazing strategies and intensities (Byrnes et al., 2018). In Patagonia, the evaluation of grazing impact on soil biodiversity is scarce and so far mostly focused on differences in microbial biomass and activity, e.g., between plant-covered patches and inter-canopy areas (Marcos and Olivera, 2016). These impacts can be positive, negative or null (Tab. 2), and more research is needed to explore such trade-offs or synergies.

\subsection{Carbon balance}

The carbon balance is addressed in a separate sub-section since it is the summary of several other aspects in the pastoral management system and, at the same time, it is one of the few ecosystem services with a potential market price. Understanding the $\mathrm{C}$ balance in the pastoral systems of Patagonia constitutes a particular area of raising political interest at the moment (MAyDS, 2020). There is a generalized concern about the contribution of livestock activity to global warming, as livestock are responsible for 14.5 to $22 \%$ of the global anthropogenic greenhouse gas (GHG) emissions (Gerber et al., 2013). However, these emissions can be partially or totally offset by $\mathrm{C}$ sequestration through improving the $\mathrm{C}$ balance at landscape level (Assouma et al., 2019). The potential to stabilize or increase the soil organic carbon (SOC) stock is highly dependent on climatic conditions, soil characteristics and grazing management (Abdalla et al., 2018). On the other hand, $\mathrm{C}$ footprints are not restricted to the farm level but to the whole production chain. Globally, the $\mathrm{C}$ footprint for extensive and intensive meat production is around 38.4-42 $\mathrm{kg} \mathrm{CO}_{2}$-eq. $\mathrm{kg}^{-1}$ carcass, respectively (Opio et al., 2013). However, $C$ stored in natural reservoirs and their potential of $\mathrm{C}$ sequestration should be considered too in assessing $\mathrm{C}$ footprints of products from grazing ecosystems (Toro-Mujica et al., 2017).

In Patagonia, Peri et al. (2020) reported a regional total C footprint of 10 to $41 \mathrm{~kg} \mathrm{CO}_{2}$-eq. $\mathrm{kg}^{-1}$ for lamb meat (carcass), and of 8 to $19 \mathrm{~kg} \mathrm{CO}_{2}$-eq kg ${ }^{-1}$ for fine-grade wool. The highest $\mathrm{C}$ footprints were found in ecologically degraded sites with lower plant productivity. Soils of the Patagonian steppe store large amounts of SOC due to their high extension in the territory (FAO and ITPS, 2018), but have low capacity to fix $\mathrm{C}$ associated to their above and below ground biomass (Tab. 3). However, the wetland meadows frequently occurring in the Patagonian steppe and locally known as Mallines, exhibit a positive balance between the sequestration of atmospheric $\mathrm{C}$ and the emissions of other GHG, such as methane and nitrous oxide (Enriquez et al., 2020). They may be considered as key $\mathrm{C}$ sink environments despite their small extension in the territory (Tab. 3). Grazing with stocking rates beyond field carrying capacity can in the long term significantly reduce above and below ground biomass and $\mathrm{C}$ stocks in Patagonian steppes (e.g., Larreguy et al., 2017) and in wetland meadows (e.g., Enriquez et al., 2020), which slowly contributes to a desertification process. 
Table 3. Carbon content and stocks in soil, below and above ground biomass in Patagonian ecosystems according to grazing intensity. Tableau 3. Teneur et stocks en carbone dans le sol, biomasse souterraine et aérienne dans les écosystèmes de Patagonie selon l'intensité du pâturage.

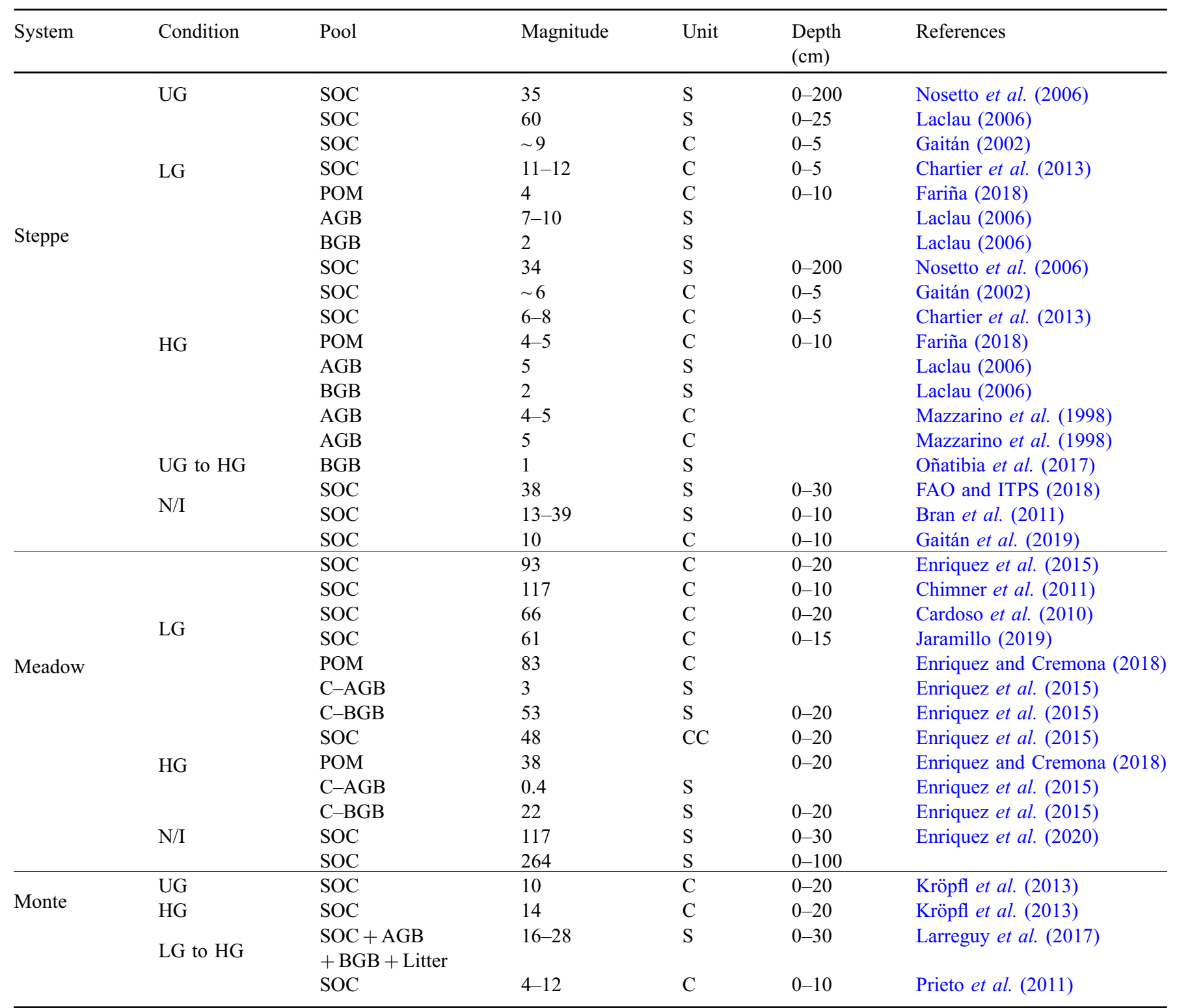

UG, LG, and HG: ungrazed, light, and high grazing intensity, respectively. SOC: soil organic carbon; POM: particulate organic matter; AGB: above ground biomass; BGB: below ground biomass; OM: organic matter; N/I: no information or specification; S: $\mathrm{C} \mathrm{stock} \mathrm{t.ha}^{-1}$; $\mathrm{C}_{\mathrm{C}} \mathrm{C}$ content g.kg ${ }^{-1}$.

With data from a representative sheep farm in North Patagonia (2500 ha and 442 sheep, Villagra et al., 2015), we calculated emission rates in the order of 36 ton $\mathrm{CO}_{2}$-eq.year ${ }^{-1}$ for enteric fermentation (which represents about $55 \%$ of total GHG emissions in small ruminant meat production- Opio et al., 2013), and 1600 ton $\mathrm{CO}_{2}$-eq.year ${ }^{-1}$ for soil respiration. We also calculated an above and below ground net primary production C fixation (Enriquez et al., 2015; Milchunas et al., 2005 ) of 5500 ton $\mathrm{CO}_{2}$-eq.year, that would offset at least three times the estimated emissions. Overall, "carbon trade-offs" related to livestock activity in Patagonia region are likely to be highly dependent on the ecological context (Fig. 1) but also on the initial condition of the grassland (i.e., grassland evaluation is needed), environmental aspects (i.e., relative to the geographic region, with wide climatic and geological variability), management strategies (i.e., intensification level, management practices), and the scale of analysis considered (i.e., farm, local, regional levels).

\subsection{Cultural ecosystem services}

Pastoral livelihoods contribute to creating and conserving traditions, knowledge and the local culture. Patagonia landscapes have been shaped by human communities since at least $12500 \mathrm{BP}$ (Ceballos, 1982) and for the last 200 years with their domestic animals (Gasteyer and Flora, 2000). Pastoral 
livelihoods have developed ecological knowledge on local resource management, medicinal and edible plants, firewood, fungi and animal species (e.g., Ladio and Lozada, 2009). For example, the conservation of local genetic resources and their ancestral knowledge include the criolla or linca sheep - of great importance for rural women-, the chiva criolla (creole goat) and the Gallina araucana local fowl (Lanari et al., 2012). The use of mammals and bird species as ethno-indicators of ecosystem quality is traditional knowledge amongst Patagonian pastoralists and also a part of their cultural heritage (Castillo and Ladio, 2017).

The different types of pastoral systems coexisting in Patagonia as described here rely on traditional forms of collective organization and natural resource governance that date from the introduction of domestic livestock in the region (Coronato et al., 2015). Even when new generations of pastoral families became sedentary, the land they managed is not always fenced or clearly demarcated, yet grazing trajectories and spots are known and respected within the community (Von Thungen, 2010). Such local by-laws and traditional institutions are also a cultural asset associated with rural livelihoods and value systems in Patagonia (Nuñez et al., 2020). Through the maintenance of such livelihoods, traditions (gastronomy, language, music, art, etc.), institutions and value systems, pastoralism undoubtedly contributes to safeguarding cultural ecosystem services in Patagonian landscapes.

\section{Conclusions}

Pastoral socio-ecological systems are essential to sustaining livelihoods in the world's harshest environments, and they support rural families on almost half of the world's terrestrial surface. They have the potential to provide a wide array of ecosystem services and protect the natural resource, base of the marginal environments where they coexist with deeply rooted pastoral cultures. In such sense, pastoralism is more than just another type of rural livelihood. It is a social-ecological system closely bound to its natural environment and the sentinel of local biocultural diversity. Yet pastoral systems are poorly understood in terms of their contribution to ecosystem services, climate change or biodiversity conservation, as the limited available evidence from Patagonia indicates. Scarce and atomized information limits our ability to assess and improve the contribution to the United Nations sustainable development goals from this vast and remote pastoral region, of high international conservation and environmental interest.

We found that pastoral socio-ecological systems of Patagonia sustain resilient livelihoods and traditional cultures, contribute to conserve biodiversity, protect landscape functionality and ecosystem services and exhibit trade-offs and possible synergies around the carbon balance. With $\mathrm{C}$ footprints between 10 to $40 \mathrm{~kg} \mathrm{CO}_{2}$-eq. $\mathrm{kg}^{-1}$ carcass, pastoral systems in dry Patagonia are below or within the range of semiextensive livestock systems worldwide $\left(35-45 \mathrm{CO}_{2}\right.$-eq. $\mathrm{kg}^{-1}$ carcass). Would Patagonia ecosystems be better off, healthier or more functional, without pastoralists? This is a rhetorical question, but it is part of an ongoing debate in the region. Pastoralists have been the custodians of the landscapes and biocultural diversity we inherited. It seems only logical to aim at minimizing, yet embracing, the socio-ecological trade-offs associated with their activities.

\section{References}

Abdalla M, Hastings A, Chadwick DR, Jones DL, Evans CD, Jones $\mathrm{MB}$, et al. 2018. Critical review of the impacts of grazing intensity on soil organic carbon storage and other soil quality indicators in extensively managed grasslands. Agriculture, Ecosystems \& Environment 253: 62-81. https://doi.org/10.1016/j. agee.2017.10.023.

ANP. 2020. Administración de Parques Nacionales. [2020/06/10] http://mapas.parquesnacionales.gob.ar/.

Assouma MH, Hiernaux P, Lecomte P, Ickowicz A, Bernoux M, Vayssières J. 2019. Contrasted seasonal balances in a Sahelian pastoral ecosystem result in a neutral annual carbon balance. Journal of Arid Environments 162: 62-73. https://doi.org/10.1016/ j.jaridenv.2018.11.013.

Bahamonde HA, Gargaglione V, Ormaechea S, Peri PL. 2012. Interacciones ecológicas en bosques de Nothofagus antarctica bajo uso silvopastoril en Patagonia sur continental. Ecosistemas 27(3): 106-115.

Ballari SA, Valenzuela AEJ, Nuñez MA. 2020. Interactions between wild boar and cattle in Patagonian temperate forest: Cattle impacts are worse when alone than with wild boar. Biological Invasions 22: 1681-1689. https://doi.org/10.1007/s10530-020-02212-w.

Basso P. 2018. Characterization and $\mathrm{N}$ flow analysis of farming systems in the Andes valleys of North Patagonia. Degree Thesis, Wageningen University \& Research (The Netherlands), $51 \mathrm{p}$.

Blackhall M, Raffaele E, Paritsis J, Tiribelli F, Morales JM, Kitzberger T, et al. 2017. Effects of biological legacies and herbivory on fuels and flammability traits: A long-term experimental study of alternative stable states. Journal of Ecology 105: 1309-1322. https://doi.org/10.1111/1365-2745.12796.

Bran D, Gaitán J, Velasco V, Easdale M. 2011. An approach to assess desertification in North Patagonia. Rosario (Argentina): International Rangeland Congress, pp. 741-745.

Buono GV, Massara Paletto L, Celdrán D. 2011. Forage availability dynamics of a Patagonian steppe under different grazing use intensities by sheep. Revista Argentina de Producción Animal 31: 135-143.

Byrnes RC, Eastburn DJ, Tate KW, Roche LM. 2018. A global metaanalysis of grazing impacts on soil health indicators. Journal of Environmental Quality 47(4): 758-765. https://doi.org/10.2134/ jeq2017.08.0313.

Cardoso BM, Chaia EE, Raffaele E. 2010. Are Northwestern Patagonian "mallín" wetland meadows reservoirs of Ochetophila trinervis infective Frankia? Symbiosis 52: 11-19. https://doi.org/ 10.1007/s13199-010-0095-x.

Castillo L, Ladio A. 2017.Mammals and birds as ethno-indicators of change: Their importance to livestock farmers in Arid Patagonia (Argentina). Environment, Development and Sustainability 20: 2161-2179. https://doi.org/10.1007/s10668-017-9983-z.

Ceballos R. 1982. El sitio Cuyín Manzano. Estudios y Documentos. Centro de Investigaciones Científicas de Río Negro 9: 1-66.

Chartier MP, Rostagno CM, Videla LS. 2013. Selective erosion of clay, organic carbon and total nitrogen in grazed semiarid rangelands of northeastern Patagonia, Argentina. Journal of Arid Environments 88: 43-49. https://doi.org/10.1016/j.jari denv.2012.08.011.

Chillo V, Amoroso MM, Rezzano CA. 2018. La intensidad en el uso silvopastoril modifica la provisión de servicios ecosistémicos a 
través de cambios en la diversidad en bosques del noroeste de la Patagonia Argentina. Ecosistemas 27(3): 75-86.

Chimner RA, Bonvissuto GL, Cremona M, Gaitán JJ, López CR. 2011. Ecohydrological conditions of wetlands along a precipitation gradient in Patagonia, Argentina. Ecología Austral 21: 329-337.

Cibils A, Fernández R, Oliva G, Escobar J. 2014. Is holistic management really saving patagonian rangelands from degradation? A response to teague. Rangelands 36: 26-27. https://doi.org/ 10.2111/Rangelands-D-14-00011.1.

Cipriotti PA, Aguiar MR, Wiegand T, Paruelo JM. 2019. Combined effects of grazing management and climate on semi-arid steppes: Hysteresis dynamics prevent recovery of degraded rangelands. Journal of Applied Ecology 56: 2155-2165. https://doi.org/ 10.1111/1365-2664.13471.

Coronato F, Fasioli E, Schweitzer A, Tourrand JF. 2015. Rethinking the role of sheep in the local development of Patagonia, Argentina. Revue d'Élevage et de Médecine Vétérinaire des Pays Tropicaux 68 (2-3): 129-133. https://doi.org/10.19182/remvt.20599.

De Paz M, Raffaele E. 2013. Cattle change plant reproductive phenology, promoting community changes in a post-fire Nothofagus forest in Northern Patagonia, Argentina. Journal of Plant Ecology 6: 459-467. https://doi.org/10.1093/jpe/rtt004.

Dong S. 2016. Overview: Pastoralism in the World. In: Dong S, Kassam KAS, Tourrand JF, Boone RB, eds. Building resilience of human-natural systems of pastoralism in the developing World. Cham, Switzerland: Springer, pp.1-37. https://doi.org/10.1007/ 978-3-319-30732-9_1.

Dudinszky N, Cabello MN, Grimoldi AA, Schalamuk S, Golluscio RA. 2019. Role of grazing intensity on shaping arbuscular mycorrhizal fungi communities in patagonian semiarid steppes. Rangeland Ecology \& Management 72(4): 692-699. https://doi. org/10.1016/j.rama.2019.02.007.

Easdale MH, Aguiar MR. 2018. From traditional knowledge to novel adaptations of transhumant pastoralists the in face of new challenges in North Patagonia. Journal of Rural Studies 63: 6573. https://doi.org/10.1002/ldr.2871.

Easdale MH, Bruzzone O, Mapfumo P, Tittonell P. 2018. Phases or regimes? Revisiting NDVI trends as proxies for land degradation. Land Degradation and Development 29: 433-445. https://doi.org/ 10.1002/ldr.2871.

Easdale MH, Fariña C, Hara S, Pérez León N, Umaña F, Tittonell P, et al. 2019. Trend-cycles of vegetation dynamics as a tool for land degradation assessment and monitoring. Ecological Indicators 107: 105545. https://doi.org/10.1016/j.ecolind.2019.105545.

El Mujtar V, Muñoz N, Prack McCormick B, Pulleman M, Tittonell P. 2019. Role and management of soil biodiversity for food security and nutrition; where do we stand? Global Food Security 20: 132144. https://doi.org/10.1016/j.gfs.2019.01.007.

Enriquez AS, Cremona MV. 2018. Testing particulate organic carbon in Patagonian wet and mesic meadows and it use as a sensitive indicator of soil degradation due to overgrazing. Wetlands Ecology and Management 26: 345-357. https://doi.org/10.1007/ s11273-017-9577-4.

Enriquez AS, Chimner R, Cremona MV. 2014. Long-term grazing negatively affects nitrogen dynamics in Northern Patagonian wet meadows. Journal of Arid Environment 109: 1-5. https://doi.org/ 10.1016/j.jaridenv.2014.04.012.

Enriquez AS, Chimner R, Diehl P, Cremona MV, Bonvissuto GL. 2015. Grazing intensity levels influence $C$ reservoirs of wet and mesic meadows along a precipitation gradient in Northern Patagonia. Wetland Ecology and Management 23: 439-451. https://doi.org/10.1007/s11273-014-9393-z.
Enriquez AS, Vangeli S, Posse G. 2020. Dinámica de las emisiones de $\mathrm{N}_{2} \mathrm{O}, \mathrm{CH} 4$ y $\mathrm{CO}_{2}$ en mallines de Patagonia Norte. In: XXVII Congreso Argentino de las Ciencias del Suelo, Corrientes, Argentina.

FAO. 2018. World Livestock: Transforming the livestock sector through the Sustainable Development Goals. Rome: Food and Agriculture Organization of the United Nations (FAO), $222 \mathrm{p}$.

FAO, ITPS. 2018. Global Soil Organic Map (GSOCmap). Technical Report. Rome (Italy), $162 \mathrm{p}$.

Fariña CM. 2018. Pastoreo intensivo en distintas estaciones del año: efectos a escala de planta y de comunidad en una estepa de Patagonia Norte. Master Thesis, Universidad Nacional de Buenos Aires (Argentina), $107 \mathrm{p}$.

Gaitán JJ. 2002. Topografía, pastoreo y vegetación como factores de control de la concentración y patrón espacial del carbono edáfico en la estepa Patagónica. Master Thesis. Universidad de Buenos Aires, $130 \mathrm{p}$.

Gaitán JJ, Bran D, Oliva G, Aguiar M, Buono G, Ferrante D, et al. 2017. Aridity and overgrazing have convergent effects on ecosystem structure and functioning in Patagonian rangelands. Land Degradation and Development 29(2): 210-218. https://doi. org/10.1002/1dr.2694.

Gaitán JJ, Maestre FT, Bran DE, Buono GG, Dougill AJ, Martinez GG, et al. 2019. Biotic and abiotic drivers of topsoil organic carbon concentration in drylands have similar effects at regional and global scales. Ecosystems 22(7): 1445-1456. https://doi.org/10.1007/ s10021-019-00348-y.

Gasteyer SP, Flora CB. 2000. Modernizing the savage: Colonization and perceptions of landscape and lifescape. Sociologia Ruralis 40: 128-149. https://doi.org/10.1111/1467-9523.00135.

Gerber PJ, Steinfeld H, Henderson B, Mottet A, Opio C, Dijkman J, et al. 2013. Tackling climate change through livestock-A global assessment of emissions and mitigation opportunities. Rome (Italy): Food and Agriculture Organization of the United Nations (FAO), 139 p.

Golluscio RA, Austin AT, García Martínez GC, Gonzalez-Polo M, Sala OE, Jackson RB. 2009. Sheep Grazing Decreases Organic Carbon and Nitrogen Pools in the Patagonian Steppe: Combination of Direct and Indirect Effects. Ecosystems 12: 686-697. https://doi. org/10.1007/s10021-009-9252-6.

Gowda JH, Kitzberger T, Premoli AC. 2012. Landscape responses to a century of land use along the northern Patagonian forest-steppe transition. Plant Ecology 213: 259-272. https://doi.org/10.1007/ s11258-011-9972-5.

Jaramillo M. 2019. Características funcionales de mallines patagónicos: adaptaciones de la vegetación a la toma preferencial de formas de nitrógeno inorgánico (amonio y nitrato). PhD Thesis, Universidad Nacional Comahue, $65 \mathrm{p}$.

Kröpfl AI, Cecchi GA, Villasuso NM, Distel RA. 2013. Degradation and recovery processes in semi-arid patchy rangelands of Northern Patagonia, Argentina. Land Degradation and Development 24(4): 393-399. https://doi.org/10.1002/ldr.1145.

Kröpfl AI, Deregibus VA, Cecchi GA. 2015. Un modelo de estados y transiciones para el Monte oriental rionegrino. Phyton 84: 390396. https://doi.org/10.32604/phyton.2015.84.390.

Laclau P. 2006. Fijación de carbono en ecosistemas boscosos y herbáceos del norte de la Patagonia. PhD Thesis, Universidad Nacional del Comahue, 369 p.

Ladio AH, Lozada M. 2009. Human ecology, ethnobotany and traditional practices in rural populations inhabiting the Monte region: Resilience and ecological knowledge. Journal of Arid Environments 73(2): 222-227. https://doi.org/10.1016/j.jari denv.2008.02.006. 
Lanari MR, Reising C, Monzón M, Subiabre M, Killmeate R, Basualdo A, et al. 2012. Recuperación de la oveja linca en la Patagonia Argentina. Actas Iberoamericanas de Conservación Animal 2: 151-154.

Larreguy C, Carrera AL, Bertiller MB. 2014. Effects of long-term grazing disturbance on the below ground storage of organic carbon in the Patagonian Monte, Argentina. Journal of Environmental Management 134: 47-55. https://doi.org/10.1016/j.jenv man.2013.12.024.

Larreguy C, Carrera AL, Bertiller MB. 2017. Reductions of plant cover induced by sheep grazing change the above-below-ground partition and chemistry of organic $\mathrm{C}$ stocks in arid rangelands of Patagonian Monte, Argentina. Journal of Environmental Management 199: 139-147. https://doi.org/10.1016/j.jenv man.2017.04.086.

Lebacq T, Baret PV, Stilmant D. 2013. Sustainability indicators for livestock farming. A review. Agronomy for Sustainable Development 33: 311-327. https://doi.org/10.1007/s13593-012-0121-x.

López DR, Brizuela MA, Willems P, Aguiar MR, Siffredi G, Bran D. 2013. Linking ecosystem resistance, resilience, and stability in steppes of North Patagonia. Ecological Indicators 24: 1-11. https:// doi.org/10.1016/j.ecolind.2012.05.014.

Marcos MS, Bertiller MB, Olivera NL. 2019. Microbial community composition and network analyses in arid soils of the Patagonian Monte under grazing disturbance reveal an important response of the community to soil particle size. Applied Soil Ecology 138: $223-$ 232. https://doi.org/10.1016/j.apsoil.2019.03.001.

Marcos MS, Olivera NL. 2016. Microbiological and biochemical indicators for assessing soil quality in drylands from Patagonia. In: Olivera NL, Libkind D, Donati E, eds. Biology and Biotechnology of Patagonian Microorganisms. Gewerbestrasse (Switzerland): Springer, pp. 91-108. https://doi.org/10.1007/978-3-319-42801-7_6.

Marino A, Rodríguez V, Schroeder NM. 2020. Wild guanacos as scapegoat for continued overgrazing by livestock across southern Patagonia. Journal of Applied Ecology 57(12): 2393-2395. https:// doi.org/10.1111/1365-2664.13536.

Marsoner T, Egarter Vigl L, Manck F, Jaritz G, Tappeiner U, Tasser E. 2018. Indigenous livestock breeds as indicators for cultural ecosystem services: A spatial analysis within the Alpine Space. Ecological Indicators 94(2): 55-63. https://doi.org/10.1016/j. ecolind.2017.06.046.

MAyDS. 2020. Segunda Contribución Determinada a Nivel Nacional de la República Argentina. República Argentina: Ministerio de Ambiente y Desarrollo Sostenible.

Mazzarino MJ, Bertiller MB, Sain C, Satti P, Coronato F. 1998. Soil nitrogen dynamics in northeastern Patagonia steppe under different precipitation regimes. Plant and Soil 202(1): 125-131. https://doi. org/10.1023/A:1004389011473.

Mazzini F, Relva MA, Malizia LR. 2018. Impacts of domestic cattle on forest and woody ecosystems in southern South America. Plant Ecology 219(8): 913-925. https://doi.org/10.1007/s11258-0180846-y.

Mazzonia E, Vazquez M. 2009. Desertification in Patagonia. In: Latrubesse EM, ed. Developments in Earth Surface Processes. Amsterdam (The Netherlands): Elsevier, pp. 351-377. https://doi. org/10.1016/S0928-2025(08)10017-7.

Milchunas DG, Mosier AR, Morgan JA, LeCain DR, King JY, Nelson JA. 2005. Root production and tissue quality in a shortgrass steppe exposed to elevated C O2: Using a new ingrowth method. Plant and Soil 268(1): 111-122. https://doi.org/10.1007/ s11104-004-0230-7.

Modernel P, Dogliotti S, Alvarez S, Corbeels M, Picasso V, Tittonell $\mathrm{P}$, et al. 2018. Identification of beef production farms in the Pampas and Campos area that stand out in economic and environmental performance. Ecological Indicators 89: 755-770. https://doi.org/ 10.1016/j.ecolind.2018.01.038.

Neary DG, Leonard JM. 2020. Effects of fire on grassland soils and water: A review. In: Kindomihou VM, ed. Grasses and grassland aspects. London (UK): IntechOpen, pp. 1-22.

Nosetto MD, Jobbágy E, Paruelo JM. 2006. Carbon sequestration in semi-arid rangelands: Comparison of Pinus ponderosa plantations and grazing exclusion in NW Patagonia. Journal of Arid Environments 67: 142-156. https://doi.org/10.1016/j.jaridenv.2005.12.008.

Nuñez PG, Michel CL, Conti S. 2020. Development challenges in the province of Río Negro, Argentina. Problemas del desarrollo 51(203): 167-190. https://doi.org/10.22201/iiec.20078951e.2020.203.69581.

Oliva G, Ferrante D, Puig S, Williams M. 2012. Sustainable sheep management using continuous grazing and variable stocking rates in Patagonia: A case study. The Rangeland Journal 34: 285-295. https://doi.org/10.1071/RJ12016.

Oliva G, Paredes P, Ferrante D, Cepeda C, Rabinovich J. 2020. Remotely sensed primary productivity shows that domestic and native herbivores combined are overgrazing Patagonia. Journal of Applied Ecology 56(7): 1575-1584. https://doi.org/10.1111/ 1365-2664.13408.

Olivera NL, Prieto L, Carrera AL, Saraví Cisneros H, Bertiller MB. 2014. Do soil enzymes respond to long-term grazing in an arid ecosystem? Plant Soil 378: 35-48. https://doi.org/10.1007/ s11104-013-2010-8.

Olivera NL, Prieto L, Bertiller MB, Ferrero MA. 2016. Sheep grazing and soil bacterial diversity in shrublands of the Patagonian Monte, Argentina. Journal of Arid Environments 125: 16-20. https://doi. org/10.1016/j.jaridenv.2015.09.012.

Oñatibia GR. 2021. Grazing management and provision of ecosystem services in patagonian arid rangelands. In: Peri PL, Martínez Pastur G, Nahuelhual L, eds. Ecosystem services in Patagonia. Natural and social sciences of Patagonia. Cham (Switzerland): Springer, pp. 47-74. https://doi.org/10.1007/978-3-030-69166-0_3.

Oñatibia GR, Aguiar MR. 2018. Paddock size mediates the heterogeneity of grazing impacts on vegetation. Rangeland Ecology \& Management 71(4): 470-480. https://doi.org/10.1016/j.rama.2018.03.002.

Oñatibia GR, Aguiar MR. 2019. Grasses and grazers in arid rangelands: Impact of sheep management on forage and non-forage grass populations. Journal of Environmental Management 235: 42 50. https://doi.org/10.1016/j.jenvman.2019.01.037.

Oñatibia GR, Aguiar MR, Semmartin M. 2015. Are there any tradeoffs between forage provision and the ecosystem service of $\mathrm{C}$ and $\mathrm{N}$ storage in arid rangelands? Ecological Engineering 77: 26-32. https://doi.org/10.1016/j.ecoleng.2015.01.009.

Oñatibia GR, Reyes MF, Aguiar MR. 2017. Fine-scale root community structure and below-ground responses to grazing show independence from above-ground patterns. Journal of Vegetation Science 28: 1097-1106. https://doi.org/10.1111/jvs.12571.

Oñatibia GR, Boyero L, Aguiar MR. 2018. Regional productivity mediates the effects of grazing disturbance on plant cover and patch-size distribution in arid and semi-arid communities. Oikos 127: 1205-1215. https://doi.org/10.1111/oik.05104.

Opio C, Gerber P, Mottet A, Falculli A, Tempio G, MacLeod M, et al. 2013. Greenhouse gas emissions from ruminant supply chains - A global life cycle assessment. Rome (Italy): Food and Agriculture Organization of the United Nations (FAO), $214 \mathrm{p}$.

Oteros-Rozas E, Ontillera-Sánchez R, Sanosa P, Gómez-Baggethun E, Reyes-García V, González JA. 2013. Traditional ecological knowledge among transhumant pastoralists in Mediterranean Spain. Ecology and Society 18(3): 33. https://doi.org/10.5751/ ES-05597-180333. 
Paul BK, Groot JCJ, Birnholz CA, Nzogela B, Notenbaert A, Woyessa K, et al. 2020. Reducing agro-environmental trade-offs through sustainable livestock intensification across smallholder systems in Northern Tanzania. International Journal of Agricultural Sustainability 18(1): 35-54. https://doi.org/10.1080/ 14735903.2019.1695348.

Pérez León N, Bruzzone O, Easdale MH. 2020. A framework to tackling the synchrony between social and ecological phases of the annual cyclic movement of transhumant pastoralism. Sustainability 12(8): 3462. https://doi.org/10.3390/su12083462.

Peri PL, Bahamonde HA, Lencinas MV, Gargaglione V, Soler R, Ormaechea S, et al. 2016. A review of silvopastoral systems in native forests of Nothofagus antarctica in southern Patagonia, Argentina. Agroforestry Systems 90(6): 933-960. https://doi.org/ 10.1007/s10457-016-9890-6.

Peri PL, Rosas YM, Ladd B, Díaz-delgado R, Pastur GM. 2020. Carbon Footprint of Lamb and Wool Production at Farm Gate and the Regional Scale in Southern Patagonia. Sustainability 12: 3077. https://doi.org/10.3390/su12083077.

Prieto LH, Bertiller MB, Carrera AL, Olivera NL. 2011. Soil enzyme and microbial activities in a grazing ecosystem of Patagonian Monte, Argentina. Geoderma 162(3-4): 281-287. https://doi.org/ 10.1016/j.geoderma.2011.02.011.

Raffaele E, Veblen TT, Blackhall M, Tercero-Bucardo N. 2011. Synergistic influences of introduced herbivores and fire on vegetation change in northern Patagonia, Argentina. Journal of Vegetation Science 22: 59-71. https://doi.org/10.1111/ j.1654-1103.2010.01233.x.

Randolph TF, Schelling E, Grace D, Nicholson CF, Leroy JL, Cole $\mathrm{DC}$, et al. 2007. Invited review: Role of livestock in human nutrition and health for poverty reduction in developing countries. Journal of Animal Science 85(11): 2788-2800. https://doi.org/ 10.2527/jas.2007-0467.

Rusch V, Cavallero L, López DR. 2016. El modelo de estados y transiciones como herramienta para la aplicación de la Ley 26331. Patagonia Forestal 1: 20-27.
Solano-Hernandez A, Bruzzone O, Groot J, Laborda L, Martínez A, Tittonell P, et al. 2020. Convergence between satellite information and farmers' perception of drought in rangelands of North-West Patagonia, Argentina. Land Use Policy 97: 104726. https://doi.org/ 10.1016/j.landusepol.2020.104726.

Tittonell P., 2014. Livelihood strategies, resilience and transformability in African agroecosystems. Agricultural Systems 126: 3-14. https://doi.org/10.1016/j.agsy.2013.10.010.

Toledo S, Gargaglione V, Montecchia M, Fontenla S, Correa O, Peri PL. 2017. Efecto de la carga ganadera sobre la biomasa microbiana del suelo en la Estepa Magallánica Seca de Santa Cruz. Corrientes (Argentina): Agrotecnia 25. REBIOS 2017. In: XI Reunión Nacional Cientifico-Técnica de Biología de Suelos, 53 p. https:// doi.org/10.30972/agr.0252469.

Toro-Mujica P, Aguilar C, Vera RR, Bas F. 2017. Carbon footprint of sheep production systems in semi-arid zone of Chile: A simulationbased approach of productive scenarios and precipitation patterns. Agricultural Systems 157: 22-38. https://doi.org/10.1016/j. agsy.2017.06.012.

Villagra ES, Easdale MH, Giraudo CG, Bonvissuto GL. 2015. Productive and income contributions of sheep, goat, and cattle, and different diversification schemes in smallholder production systems of Northern Patagonia, Argentina. Tropical Animal Health and Production 47(7): 1373-1380. https://doi.org/10.1007/ s11250-015-0873-9.

Villagra ES, Pelliza A, Willems P, Siffredi G. 2013. What does domestic livestock eat in Northern Patagonian rangelands? Animal Production Science 53(4): 360-367. https://doi.org/10.1071/ AN11283.

Von Thungen J. 2010. Profitability of sheep farming and wildlife management in Patagonia. Pastoralism 1: 274. https://doi.org/ 10.3362/2041-7136.2010.015.

Von Thungen J, Martin E, Lanari MR, 2021. Controversies and common ground in wild and domestic fine fiber production in Argentina. Frontiers in Sustainable Food Systems 5: 24. https://doi. org/10.3389/fsufs.2021.550821.

Cite this article as: Tittonell P, Hara SM, Álvarez VE, Aramayo VM, Bruzzone OA, Easdale MH, Enriquez AS, Laborda L, Trinco FD, Villagra SE, El Mujtar V. 2021. Ecosystem services and disservices associated with pastoral systems from Patagonia, Argentina-A review. Cah. Agric. 30: 43 . 